\title{
QUEEN'S
UNIVERSITY
BELFAST
}

\section{Trends and Determinants of Work-Retirement Transitions under Changing Institutional Conditions: Germany, England and Japan compared}

Hofacker, D., Schroder, H., Li, Y., \& Flynn, M. (2016). Trends and Determinants of Work-Retirement Transitions under Changing Institutional Conditions: Germany, England and Japan compared. Journal of Social Policy, 45(1), 39-64. https://doi.org/10.1017/S004727941500046X

Published in:

Journal of Social Policy

Document Version:

Peer reviewed version

Queen's University Belfast - Research Portal:

Link to publication record in Queen's University Belfast Research Portal

Publisher rights

Copyright (C) Cambridge University Press 2015

\section{General rights}

Copyright for the publications made accessible via the Queen's University Belfast Research Portal is retained by the author(s) and / or other copyright owners and it is a condition of accessing these publications that users recognise and abide by the legal requirements associated with these rights.

Take down policy

The Research Portal is Queen's institutional repository that provides access to Queen's research output. Every effort has been made to ensure that content in the Research Portal does not infringe any person's rights, or applicable UK laws. If you discover content in the Research Portal that you believe breaches copyright or violates any law, please contact openaccess@qub.ac.uk. 


\title{
TRENDS AND DETERMINANTS OF WORK-RETIREMENT TRANSITIONS UNDER CHANGING INSTITUTIONAL CONDITIONS: GERMANY, ENGLAND AND JAPAN COMPARED
}

\section{DIRK HOFAECKER $*$, HEIKE SCHRODER $* *$, YUXIN LI $* * *$ AND MATTHEW FLYNN****}

* University of Duisburg-Essen, Institute of Social Work and Social Policy, Berliner Platz 68, 45127 Essen, Germany, Email: dirk.hofaecker@uni-due.de

** Queen's University Belfast, Queen's Management School, Riddel Hall, 185 Stranmillis Road, Belfast, BT9 5EE, United Kingdom, Email: h.s.schroder@gmail.com

*** University of Warwick, Institute for Employment Research, Room B0.30, Coventry, CV4 7AL, United Kingdom, Email: yuxin.li@warwick.ac.uk

**** Newcastle University Business School, Centre for Research into the Older Workforce (CROW), 5 Barrack Road, Newcastle upon Tyne, NE1 4SE, United Kingdom, Email: matt.flynn@ncl.ac.uk

\begin{abstract}
Many governments world-wide are promoting longer working life due to the social and economic repercussions of demographic change. However, not all workers are equally able to extend their employment careers. Thus, while national policies raise the overall level of labour market participation, they might create new social and labour market inequalities. This paper explores how institutional differences in the United Kingdom, Germany and Japan affect individual retirement decisions on the aggregate level, and variations in individuals' degree of choice within and across countries. We investigate which groups of workers are disproportionately at risk of being 'pushed' out of employment, and how such inequalities have changed over time. We use comparable national longitudinal survey datasets focusing on the older population in England, Germany and Japan. Results point to cross-national differences in retirement transitions. Retirement transitions in Germany have occurred at an earlier age than in England and Japan. In Japan, the incidence of involuntary retirement is the lowest, reflecting an institutional context prescribing that employers provide employment until pension age, while Germany and England display substantial proportions of involuntary exits triggered by organisational-level redundancies, persistent early retirement plans or individual ill-health.
\end{abstract}




\section{KEY WORDS}

retirement transition; voluntary retirement; involuntary retirement; Germany; Japan; England

\section{INTRODUCTION}

Between the 1970s and 1990s, many Western societies promoted early labour market exit through (institutional) pathways (Kohli and Rein, 1991) that included state-financed monetary incentives, state-sponsored early retirement initiatives (Blossfeld et al., 2006) and/or occupational pension schemes (Ebbinghaus, 2006), and guaranteed a sufficient standard of living throughout retirement. Therefore, government and employers used these routes to manage job attrition resulting from industrial transformation by shifting older workers out of work (Walker 1998), particularly men in blue-collar jobs (Hirsch, 2003). While in 1960, around 75 per cent of men aged 60 to 64 were in active employment across Western industrialised countries, this declined to less than 50 per cent by the mid-1990s, though with notable crossnational differences (OECD, 2005).

Given population ageing and predicted labour shortages, early retirement was increasingly considered unsustainable due to concerns about its affordability and impact on economic growth (Blossfeld et al., 2011). Early retirement was furthermore criticised because of its negative effects on the income security of the older population (Walker, 1980) and its role in intensifying negative stereotypes about productivity at old age (Walker, 2005). The latter was a result of a downward redefinition of the beginning of "old age", which exacerbated existing age discrimination in employment (Walker and DLitt, 2000). The mid- to late-1990s were therefore marked by conflicting trends: while institutionalised early retirement persisted, governments and employers in OECD countries had started to reassess its usefulness (Walker, 1998). Therefore, since the 1990s due to economic and social pressures and later to implement the European Union (EU) Lisbon Protocol, European national governments (including the United Kingdom (UK) and Germany), have introduced measures to discourage early retirement and to promote longer working lives (Phillipson, 2013). Such measures are considered a part of 'active ageing', a policy framework covering health, eldercare, inclusion and work (Walker, 2002). In Japan, due to low birthrates and limited migration, the government has promoted extended working life already since the 1960s (Higo and Yamada, 2009), but has recently sought to reduce the contingency in which most older workers find themselves by investing heavily in special job placement services and by compelling employers to retain their workers beyond their firm-level mandatory retirement age, often age 60, until the new national pension 
age of 65 (Flynn, Schroder, Higo and Yamada, 2014). However, even though employment rates of older individuals have generally increased markedly since the late-1990s (OECD, 2013), not all individuals are equally able to prolong their employment due to intra-group heterogeneities (Bennett and Möhring, 2015). Lower-educated workers face particular difficulties in remaining in or finding new employment, and are thus at a higher risk of being 'pushed' out of the labour market before reaching pension ages (Blossfeld et al., 2011).

While there is literature on early retirement and its drivers (see: Kohli and Rein, 1991, Walker, 1985, OECD, 2011), there has been little focus on its recent reversal. This holds especially for whether retirement transitions are perceived as an individual choice or whether, for example, employer practices favouring younger workers force older workers into retirement (Wood et al., 2008). This paper has two aims. First, we chart the development in the timing of retirement in three countries. Second, we investigate individual retirement motives. Here, we determine who is disproportionately at risk of being permanently 'pushed' out of employment involuntarily before reaching pension age, and how this has changed over time. Our particular focus lies on establishing a longitudinal perspective that allows to trace developments in timing and motives across time as welfare and labour market institutions have gradually shifted from a policy of early retirement to promoting longer working life (see above).

We selected Germany, the UK and Japan because they similarly face population ageing (Christensen et al., 2009) but diverge regarding the labour market participation of those aged 50 or over (OECD, 2014). Literature has related these cross-national differences to different institutional configurations that mold employment participation (Ebbinghaus, 2006, Blossfeld et al., 2006), as postulated in the "Varieties of Capitalism" (Hall and Soskice, 2001) literature. The selected countries differ in their incentives for early retirement (Blöndal and Scarpetta, 1999) and in the degree to which labour market regulation, industrial relation systems and firm policies impede or foster employment at old-age (Ebbinghaus, 2006, Ebbinghaus and Hofaecker, 2013, Flynn, Upchurch, Muller-Camen and Schroder, 2013). We investigate how such configurations affect individual retirement decisions, the degree of choice they afford, and whether there are differences between labour market groups. Due to data restrictions, we cannot analyse UK data but focus on England, even though we acknowledge that public policy changes have affected the entire UK. Section 2 outlines theoretical concepts and establishes hypotheses. Following the presentation of data and methods, we provide empirical evidence. A discussion and summary conclude the paper. 


\section{COMPARING INSTITUTIONAL CONTEXTS}

Various approaches attempt to explain cross-national variations in retirement patterns (Hofaecker, 2010). Mostly, retirement is conceptualised as an individual decision under given opportunity structures defined by national, workplace and socio-demographic factors. Literature categorises these contextual backgrounds into three groups (Ebbinghaus, 2006; Ebbinghaus and Hofaecker, 2013): 'pull', 'push' and 'retention' factors. Pull factors are (economic) incentives in welfare state systems that provide financially-attractive labour market exit opportunities. Blöndal and Scarpetta (1999) show that countries that provide actuarial incentives for early retirement also tend to exhibit low old-age employment ratios. Occupational pensions exert additional incentives. These incentives may reinforce each other, leading to strong retirement stimuli (Dorn and Sousa-Poza, 2010). Push factors, in contrast, assume that work-retirement decisions are not simply taken under given financial constraints, but that certain factors force workers from employment against their deliberate preferences. Recently, policies to retain older workers in employment have gained importance. These retention factors (Ebbinghaus and Hofaecker, 2013), or activation policies (Van Berkel et al., 2007), include lifelong learning and active labour market policies that aim to enhance (older) workers' employability. Yet, not all older workers benefit similarly from such policies (Blossfeld et al. 2011). This is because of significant biases in access to and participation in lifelong learning which concentrates on those with a higher initial education, especially where the incidence of lifelong learning is low (OECD, 1999). Furthermore, although the opportunity to change jobs or work routine might keep older workers motivated, actual take-up is low mainly because of worries about the impact on the security of retirement income (Maitland, 2010). Finally, while attention has been paid to employer interventions to prevent ill-health-related retirement, such programmes have been difficult to implement for those in manual jobs (Weyman and Buckingham, 2013).

This paper compares Germany, the UK and Japan because they reflect distinct combinations of pull, push and retention factors, both in their institutional heritage and in their recent policy developments. These configurations shape retirement patterns and affect the nature of intranational inequalities. In Japan, retirement ages are traditionally high and employment rates have remained above those of most Western economies. Japan is therefore considered a late exit regime (Ebbinghaus, 2006). Since the 1950s, a main macro-economic challenge has been the supply and retention of skilled labour. Employers' Human Resource Management (HRM) practices therefore included the provision of long-term job security, age-based pay systems, and mandatory retirement rules. Employers could set a mandatory retirement age of 55 until 1994 
when this rose to 60, and will gradually rise to 65 by 2025 (Oka, 2013). While employers worry about losing skills, they are also reluctant to retain older workers without government assistance to offset high seniority-based labour costs (Seike and Yamada, 2004). Employers thus frequently use redeployments to move workers after their mandatory retirement ages within and between workplaces (Flynn et al., 2014). Furthermore, small and medium-sized enterprises seek older displaced workers to offset skills shortages (Casey, 2005). Nevertheless, these practices are regularly accompanied by significant salary cuts, demotions and loss of job security (Oka, 2013, Yamada and Higo, 2011). Since the 1960s, workers could draw their pensions while staying in work, allowing the government to hold down pension costs without creating old-age poverty, despite low replacement rates (OECD, 2011). Therefore, while Japanese governments have not institutionalised and financed early retirement schemes, firm-level mandatory retirement rules caused a de-facto "early exit" culture. Current public policies attempt to extend working lives by enabling workers to remain employed at least until age 65 .

In contrast, Germany has a history of institutionalised early retirement, which has only recently started to reverse (Hofaecker and Naumann, 2015). Until 2000, labour market participation among those aged 50 or over was low, partly due to labour market and welfare state policies that aimed to reduce youth unemployment and provide organisations with socially-acceptable means to lay-off staff (Trampusch, 2003). During these years, a strong internal labour market system, high employee involvement and job security, and a front-loaded education system created a labour market structure in which younger workers with recent qualifications and lower wages were favoured over older unemployed individuals (Blossfeld et al., 2006). Especially lower-skilled workers thus used incentives to retire early, mostly at financially-acceptable terms. Only recently, these push and pull forces were mediated by a change in political climate towards 'active ageing'. Pension and welfare systems were reformed to reduce the financial attractiveness of early retirement and to close off state-financed early retirement pathways (Muller-Camen at al., 2011). The government also implemented active labour market measures targeting older individuals. Nonetheless, Germany does not yet place much emphasis on lifelong learning measures and, if so, lower-skilled employees are often excluded (Schroder et al., 2009).

Unlike other parts of Europe, the UK has not featured state-sponsored early retirement since the Job Release Scheme was phased out for new claimants in 1988 (Banks et al., 2008). However, occupational pension schemes are still used to pay for early retirement, though only for a select group of highly-educated individuals with full work histories (Fasang, 2010) and for specific occupational groups such as in the steel sector (Flynn et al., 2013). The government 
takes a minimal role in social provision and workplace regulation (Schroder et al., 2014). As a result, the labour market itself and the acquisition of work-specific skills is flexible, allowing for adaptations to changing market demands across age groups. Furthermore, the 2006 Employment Equality (Age) Regulation (now: Single Equality Act 2010), that was discussed and implemented based on EU directive 2000/78/EC from 2000, prohibits workplace age discrimination. Since 2011, compulsory retirement is only lawful in occupations in which job specifications justify it and from 2006, the government had been preparing employers for managing without a compulsory retirement age (Flynn, 2010). The State Pension Age (SPA) is currently being equalised to 65 for both genders, and is projected to rise further. Yet, only modest activation measures have been introduced. The UK is therefore not an early exit regime as is Germany. However, its comparatively high retention of older workers in employment results less from explicit public or employer-led retention policies as seen in Japan. It is rather an individual-level financial necessity to remain employed, since the state pension only accounts for 42 per cent of pension expenditure, with most of the remaining pensions coming from occupational pension schemes (OECD, 2011). Particularly for low-skilled workers, who often only have access to public pension schemes, this creates financial pressures to remain employed; a trend that is expected to increase as public pension eligibility ages rise further (Lain, 2012). Table 1 compares institutional characteristics, their developments, and patterns in social inequality.

Table 1

It is difficult to directly measure the significance of push, pull and retention factors in explaining retirement transitions. Many studies therefore focus on the retirement transition per se, and establish its characteristics indirectly by assessing the effects of covariates. If, for example, low-qualified workers retire early, this is taken as an indication of the prevalence of high labour market pressures, i.e. push factors (Blossfeld et al., 2006). However, the meaning of determinants may be ambiguous. The higher likelihood of older workers with low qualifications retiring early might equally be due to the relative financial attractiveness of early retirement pathways (pull factors). The true retirement reason thus cannot be ascertained by the effect of explanatory variables on exit behaviour. Furthermore, early retirement is often a result of a combination of push and pull factors (Reeuwijk et al., 2013). From a public policy perspective, it therefore has to be acknowledged that the elimimination of corresponding incentives may not 
necessarily lead to older workers delaying retirement since people who are in physicallydemanding or stressful work may still try to retire early even without financial incentives (DePreter et al., 2013). Moreover, conclusions about retirement transitions do not necessarily correspond with perspectives of individuals themselves. Individuals who retired early based on financially-generous opportunities may not consider this a free decision, if no acceptable alternative existed (Quine et al., 2007).

To assess the nature and drivers of retirement transitions, more knowledge is required about actual motives of individuals for making their retirement transition. However, only recently, relevant measurements have become available, like the Survey of Health, Ageing and Retirement in Europe, which includes an indicator that distinguishes between retirement reasons. Using this indicator, Koenen et al. (2009) establish categories of voluntary and involuntary retirement. Voluntary retirement refers to personal or health reasons, and includes those who reached pensionable ages and exited employment despite the opportunity to continue working. In contrast, involuntary retirees are individuals who were dismissed or offered early retirement, and who retired after reaching an age limit without opportunities for work continuation.

Building on Koenen et al. (2009), we hypothesise that there will be differences between Germany, England and Japan regarding the retirement transition timing. Japanese workers are expected to retire latest, given the overall supportive context, followed by English workers and then, despite recent reforms, German workers (Hypothesis H1a). Furthermore, we expect the degree of choice in making the transition to be highest in Japan (where individual redeployment contracts mostly allow for a flexible retirement transition according to personal preferences) and to be lowest in Germany (where a comparatively rigid labour market still provides obstacles to continued employment). England is expected to take an intermediate position (H1b).

We further assume that individual factors influence retirement transitions. These include human capital, gender, and birth cohort. Their effects may, however, vary within countries, as institutional configurations may create differential conditions for retirement decisions for specific groups. Using formal educational qualification ${ }^{\mathrm{i}}$ as a proxy for human capital, we anticipate that, in Germany, those with low and medium-level qualifications are most prone to involuntary retirement, given their disadvantages in a rigid labour market system. This trend might be weaker in England where lower-skilled employees in particular have had better opportunities to adapt to changing labour market demands, and to work longer, if needed (McNair et al., 2004). Nonetheless, their stronger financial necessity to work might lead to 
involuntary retirement in comparison to the higher-skilled, given the latter's higher freedom to navigate their retirement transition, combining different old-age income sources. For Japan, we anticipate that low and medium-qualified individuals profit from redeployment opportunities until pension age. Only regarding employment after formal retirement age, educational cleavages might increase (H2).

We further anticipate gender differences (H3) in the retirement timing, given that women can frequently draw their pensions earlier (Germany and England) and often display a more marginal labour market attachment than men (Germany and Japan) (Blossfeld et al., 2006; Abe, 2011). Given this differential labour market attachment, we expect that the degree of voluntariness varies, with higher levels of voluntary retirement for women (relative to men) in Germany and Japan than in England. Germany and Japan are traditionally known as 'male breadwinner' societies (Blossfeld et al., 2006; Abe, 2011) and women are expected to retire more often for personal/family reasons and to be less affected by company-led retirement schemes.

We anticipate differences in retirement transitions over time, where transitions occur later for those retiring in the 2000s, given the institutional re-orientation towards later retirement (as compared to those retiring in the 1990s where early retirement policies were dominant) (H4). Furthermore, we expect that, over time, the incidence of involuntary retirement declines, as institutional reforms allow individuals to work up to higher ages and to exert more individual choice in their retirement decisions. We expect that this effect is strongest in Germany, where institutionalised early retirement has been most entrenched and where the change in public policy has been most pronounced, while England and Japan did not offer institutionalised and state-financed early retirement to the same degree.

Lastly, we test for cross-level interactions between socio-demographic characteristics and time. As not all workers are similarly able to benefit from 'active ageing' measures (Blossfeld et al. 2011), we assume that social inequalities have increased over time (H5). This effect may especially occur for education. For Germany, we assume that individuals with low compared to medium-level education might increasingly be forced to continue working for financial reasons. Simultaneously, opportunities to do so might be restricted, given the disproportionate concentration of lifelong learning measures on the more highly educated. We thus expect that particularly among lower-educated German workers, the rising expectation to work longer and the only modest increase in opportunities to do so results in a higher risk of involuntary 
retirement. Given the tradition of lifelong learning in the UK (McNair, 2010) and the more supportive policy of the Japanese government (Flynn et al., 2014), no such effects are expected.

\section{DATA AND METHODS}

We use three national surveys focusing on the employment and living conditions of the older population. For Germany, we use the Survey of Health, Ageing and Retirement in Europe (SHARE) $)^{\mathrm{ii}}$, a longitudinal panel survey of the population aged 50 or over in 20 European countries, providing representative information on employment decisions. We use pooled data from the baseline wave (2004/5) and the first longitudinal wave (2006/7). For England, we use the English Longitudinal Study of Ageing (ELSA) ${ }^{\text {iii }}$, a representative longitudinal survey of the population aged 50 or over. We use the first three waves (2002, 2004, 2006) as some individual information was not available for the 2008 wave. The Japanese Study of Health, Ageing and Retirement (JSTAR) ${ }^{\text {iv }}$ covers older individuals in five Japanese municipalities. Wave 1 was conducted in 2007, with a follow-up in 2009. Since the item exploring retirement motives was changed in 2009, we restrict our analyses for reasons of analytical parsimony to the 2007 wave. Generally, we have restricted our analysis to data collected before the 2008 global financial crash, after which there has, in Europe at least, been a resurgence in the use of early retirement (EUROFOUND, 2012).

The main dependent variables are the retirement age, and self-reported reasons for retirement. Since the surveys started relatively recently, retirement transitions that took place during the survey period cannot cover the entire period within which public policy changed from 'early retirement' to 'active ageing' (the change in political climate for the UK and Germany being manifested in the publication of the EC 2001 Lisbon Protocol and globally the 2002 United Nations Madrid International Action Plan on Aging). Retrospective information on retirement timing and motives is thus used for transitions before the survey started. To reduce memory errors, we only include respondents who had retired throughout the 15 years prior to the interview, nevertheless, allowing us to analyse retirement transitions in the 1990s and the 2000s. We are thus able to observe cross-national differences in retirement transitions and their developments over time. Even though we cannot capture most recent years due to problems of data availability and comparability of the latest waves, this approach allows us to go well beyond existing literature, that often focuses on transitions under just one institutional regime (i.e. Blossfeld et al., 2006, 2011), by comparing the significance of institutional policy shifts across three countries. The drawback of this retrospective approach is that there is no 
information on time-varying covariates. We thus only use time-constant covariates (gender; age), factors that are largely time-invariant (highest education attained) and information about the last employment relationship prior to entering full-time retirement (firm characteristics) as explanatory variables. These selections lead to unweighted sample sizes of 5172 respondents (2617 men, 2555 women) for ELSA, 1549 (909 men, 640 women) for SHARE and 892 (468 men, 424 women) for JSTAR.

We define retirement timing based on self-reported permanent cessation of employment. This seems more appropriate than the 'year of first pension receipt', which may reflect national regulations rather than actual withdrawal from employment. Self-reported assessment of employment exit avoids the difficulty of having to define retirement externally which has become difficult in times when phased retirement or working while being retired have become widespread. Self-assessment therefore helps to identify effective labour market withdrawal. However, it does not allow us to determine whether retirees re-entered employment after the interview. The variable age at retirement is therefore the self-reported employment exit age in ELSA and JSTAR, and is reconstructed based on the year in which the last job ended and the respondent's birth year in SHARE. To exclude extreme cases of early/late withdrawal, we only consider retirement transitions between age 50 and 70 .

Reasons for retirement are constructed based on a retrospective question. The reasons are divided into 'voluntary' and 'involuntary' categories. Categorisations employed by the surveys mostly allowed for identical coding. However, some country-specific peculiarities necessitated a case-specific differentiation. Overall, we assume that reaching the eligibility for drawing a pension reflects a voluntary transition because individuals are expected to have left employment although they had the choice to stay. Only the German dataset explicitly differentiates between cases in which individuals had the opportunity to continue working (voluntary), and those where this opportunity did not exist (involuntary). A similar logic is applied for German employment exits based on firm-level early retirement plans and for the Japanese practice of redeployment (Casey, 2005). Retirement due to personal reasons is considered voluntary, while retirement due to ill-health, redundancy, dismissal or plant closure is considered involuntary (compare: Koenen et al., 2009). For England and Japan, those who were not able to find employment despite search efforts, and therefore took retirement, are also considered 'involuntary' retirees. Table 2 summarises these categorisations.

Table 2 
We investigate social inequalities in retirement transitions by differentiating individuals according to socio-demographic characteristics. To account for age-specific differences, we introduce four dummy variables reflecting 5-year time bands from age 50 to 69 (50-54, 55-59, 60-64, 65-69). These groups reflect typical age bands in which individuals could access pensions. In the UK, until 2010, the earliest ages men and women could claim their full state pension were 65 and 60, respectively. In Germany, generous early retirement options in the 1990s allowed for employment exits already in the mid- to late-50s. In Japan, however, exits before age 60 have been rare which led us to collapse the two dummies for the 50s age groups in the Japanese analyses.

Dummies for highest educational attainment controlled for differences in social capital: lower secondary education or less (ISCED 0-2); upper secondary education (ISCED 3-4) and tertiary education (ISCED 5 and higher). Gender is controlled for by a dummy. Furthermore, time period dummies differentiate between retirement transitions in the 1990s and 2000s to account for retirement changes throughout the gradual policy shift from early exit policies in the 1990s to active ageing in the 2000s. Even though these decades only offer very broad reflections of concrete policy changes, they may serve as valuable proxies of more general shifts in political strategies across time. Interaction effects between the period dummies and the aforementioned characteristics are introduced to investigate whether effects changed over time. Finally, in order to account for cross-country differences in economic structure, we include variables at the firmlevel. We use number of employees at the workplace to differentiate between small (0-24 employees), medium-sized (25-199) and large companies (200plus). For Germany, data on sector of employment differentiates between firms in the primary, secondary or tertiary sector. Lastly, a dummy differentiates private from public sector organisations.

We first present descriptive country-level results of retirement timing and the incidence of voluntary/involuntary retirement. We account for social inequalities by disaggregating results by socio-demographic characteristics. We consider relationships between these dimensions by estimating multinomial logistic regression models predicting the likelihood of voluntary versus involuntary retirement. To compare results across samples (Mood, 2010), we report marginal effects which provide quantified measures on how much the dependent variable is expected to change for a unit change in an independent variable for the control variables (though not for the interaction terms). The marginal effect of the interaction term is the cross-partial derivative of the expected value of the dependent variable with respect to an independent variable. However, 
in non-linear models, this is not the same as the first derivative of the dependent variable on the product of two independent variables. Thus the methods used to compute marginal effects do not apply to interaction terms. Odds ratios are reported instead, which indicate the ratio by which the dependent variable changes for a unit change in an explanatory variable. It therefore shows the effect of independent variables on the expected number of people having voluntary retirement for every person with involuntary retirement. In Tables 4-6, if an odds ratio equals 1 , this signifies that a change in the independent variable does not affect the likelihood of voluntary retirement. If an odds ratio is larger (smaller) than 1 , a change in the independent variable will increase (decrease) the likelihood of voluntary retirement.

\section{RESULTS}

\subsection{Descriptive results}

Table 3 provides an overview of the average retirement age, the incidence of involuntary retirement on an aggregate level, and breakdowns by socio-demographic groups. Tables A1A3 show the actual retirement reasons.

Tables 3 and A1-A3

Involuntary retirement is a widespread phenomenon in Germany (Dorn and Sousa-Poza, 2010). Looking at all retirement transitions since the 1990s, involuntary retirement in Germany occurs mainly among those aged in their 50s (Table 3). This is due to a high incidence of ill-healthrelated retirement (Table A1). Furthermore, it is also around this age that most employer-led retirement transitions, for example through dismissals, are reported. This indicates the longlasting German early retirement tradition at the time of data collection, where public early retirement pathways were often supplemented through occupational pensions. The persistent importance of such occupational programmes across the entire observation period suggests that the public policy shift has not yet sufficiently affected firm-level policy.

In line with our hypotheses, gender-specific figures indicate that involuntary retirement in Germany is largely a male phenomenon (Table 3), reflecting that men are more often subject to institutionalised early retirement plans. Furthermore, given their higher retirement ages throughout the past 20 years (men: 65; women: practically 60) and their more frequent 
employment in physically-demanding jobs, men face higher ill-health-related retirement risks. In contrast, women exit more often through the public pensions pathway, which is available to them at an earlier age (Table A1).

No simple pattern emerges regarding educational background. Highly-educated individuals work longest and have a higher likelihood of retiring due to eligibility for public or occupational pensions. Individuals with lower levels of education, as expected, face higher work-related health risks and are more likely to leave earlier. A high number of individuals with lower levels of education also claim to exit via eligibility to public pensions, which may be because they have accumulated necessary pension contribution years at a younger age, given their shorter educational history. Involuntary retirement is highest among workers with an upper secondary education. This may be because they lack transferable human capital compared to tertiary graduates, but have not yet accumulated necessary contribution years to exit via public pension pathways. This group might therefore be most strongly affected by firm-based measures to 'push' workers into retirement.

Results for firm-level control variables show that involuntary retirement is particularly common in larger German firms, possibly because these firms face higher rationalisation demands and are more likely to implement early retirement schemes. Finally, the incidence of involuntary retirement indeed decreased between the 1990s and the 2000s, suggesting that under the 'active ageing' regime in combination with overall favourable economic conditions, older employees are more likely to reach public/occupational pension eligibility ages and to retire voluntarily.

Results for the ELSA data indicate that there exist notable differences between England and Germany concerning the retirement timing and its causes. As expected, retirement in England occurs later for men and women. Furthermore, the incidence of involuntary retirement lies around 10 per cent lower than in Germany, reflecting the liberal market orientation with more flexible labour market policies. As in Germany, English women exit employment earlier than men, given their then lower SPA (60 compared to 65). However, there is no gender difference in the incidence of involuntary retirement, which ranges around 40 per cent for both sexes. Nevertheless, the analysis of retirement reasons points to gender inequalities: while men are more likely to exit via employer-provided pre-retirement schemes, women frequently retire for personal reasons, suggesting that even within the UK model women follow a less marketdependent retirement logic than men.

Differences to Germany also emerge across age groups. Unlike the German inverse U-shaped pattern, involuntary retirement in England shows fewer age differences. Even for those who are 
beyond public pension eligibility age, a substantial proportion report involuntary retirement. This is because public retirement ages are less important in structuring life course transitions than in Germany (Leisering, 2003). Instead, retirement timing in England depends on the individual financial affordability. Notably, those in their 50s more often retired for personal reasons, while health was a concern for those in their late-50s and early-60s. Especially this latter group may represent a problem group that is prevented from working despite having the financial need to do so. Average retirement age declines with higher education in England, while such workers more often retire voluntarily, especially through occupational pension schemes. In contrast, lower-educated workers are more likely to face labour market risks, including redundancies and ill-health. Retirement therefore depends on having financial resources rather than on institutionalised pension requirements. This creates greater choice for those who can afford retirement. However, those with fewer financial resources are faced with a continuing need to work, even if labour market or health conditions create obstacles. Finally, a comparison across time periods reveals that, similar to Germany, the incidence of involuntary retirement has decreased for the younger cohort, although in England, the effect remains rather modest.

For Japan, a problem for the analysis arises from gender differences in the reporting of labour market exits. While men predominantly claim to have transitioned from employment into retirement, women indicate to have transited into 'housekeeping' (compare: Ichimura and Shimizutani, 2012), even when having been employed in their 50s. These results reflect the overall weak labour market attachment of women, who are largely excluded from the lifetime employment system (Abe, 2011). This differential response behaviour entails that, due to questionnaire filtering, most Japanese women were not asked the item battery of 'retirement reasons' (Table 2), but received alternative, 'housekeeping'-related answer categories that are not comparable with work-related motives. To increase the cross-national comparability, we therefore only refer to Japanese men.

Our results point to notable differences in Japanese retirement behaviour compared to Germany and England. With an average retirement age of 62.8, Japanese men retire latest. Virtually no retirement occurs prior to age 60, with peaks at 60 and 65. Around 20 per cent work beyond age 65. In line with our hypotheses, retirement transitions are more voluntary than in Germany and England. Intra-national differences are, however, observed. Japanese men with tertiary education retire earlier and more often voluntarily than those with lower education levels. An explanation might be that higher-educated men are better able to afford retirement and are more frequently offered redeployment/rehiring alternatives after age 60, thus experiencing more 
choice in their retirement decisions. Those with a lower level of qualification may need to work longer for financial reasons. Yet, they are more likely to experience ill-health, restricting their degree of choice.

Average retirement age is highest in small firms: almost a third of employees retired due to illhealth, leading to a relatively high share of involuntary exits. Yet, when excluding ill-health, retirement is mostly voluntary. In large firms, older workers retire earlier and more voluntarily, the latter possibly because they more frequently receive redeployment/rehiring offers. Trends over time indicate that retirement increasingly occurs at later ages (Shimizutani, 2011). Yet, this trend is accompanied by higher levels of ill-health-related, and thus involuntary, retirement (Table A3).

\subsection{Multivariate results}

Although the descriptive analyses provide insights into the nature of retirement transitions and their differential spread across socio-demographic groups, their bivariate nature restricts an assessment of social inequality patterns over time. We therefore conduct multivariate logistic regressions on the relative likelihood of being affected by involuntary retirement.

Table 4

Table 4 presents the marginal effects and odds ratios of the logistic regression for Germany. These results are consistent with findings from the descriptive analysis. Voluntary retirement is most widespread among those in their 60s who were subjected to firm-level rationalisation measures. Also, involuntary retirement is more frequent among men than women, and among workers with lower levels of education. However, the latter effect decreases once ill-healthrelated retirement is excluded from the analysis. If lower-educated workers' health allows them to work longer, they enjoy a higher level of choice, given their then higher likelihood to retire through regular pension pathways. However, even if low-educated workers retire involuntarily due to ill-health, these exits are financially-shielded given the comparative generosity of German disability benefits. This, however, may change, because pension reforms have closed disability-related early retirement routes. Interaction effects between time period and education suggest that the advantage of higher-educated workers has weakened, as the likelihood of involuntary exit has increased since the 1990s. Firm-level determinants are less important. 
Employees in small firms retire voluntarily as do employees in larger firms. Notably, this positive effect only emerges once controlling for education (own analyses, not shown here), indicating that the high share of involuntary retirement in large firms might be due to firmspecific non-transferrable skills.

Table 5

Table 5 shows the results from England. Again, these mostly confirm the descriptive findings. Age-graded patterns are less pronounced than in Germany, and it is only when a person is in their late-60s or beyond, and when sufficient resources for retirement have been secured, that retirement becomes more voluntary. Similarly, gender differences are small, especially when considering health-related reasons. Unlike in Germany, lower-educated workers experience involuntary retirement, even when excluding ill-health. This reconfirms the conflict within the liberal pension system between the financial need to continue working and possibly limited health and human capital resources to do so. Trends over time suggest that the likelihood to retire voluntarily has increased. Yet, contrary to our expectations, differences between education groups decreased. This effect disappears once excluding ill-health-related retirement, suggesting a decrease in ill-health across the two labour market cohorts.

Table 6

Finally, Table 6 presents Japanese results. Due to the small sample size (resulting from the exclusion of women), results are less pronounced. However, they reconfirm the picture of a peak of voluntary retirement when reaching the (late-)60s. Although the effect reaches only marginal statistical significance, results corroborate the disadvantaged position of lowereducated workers who more often exit involuntarily.

\section{CONCLUSIONS}

Using comparable surveys for England, Germany and Japan to investigate the timing of and motives for work-retirement transitions, we focus on whether this transition occurs voluntarily or involuntarily. We suggest that institutional contexts influence individuals' degree of choice 
over and the timing of this transition. As these countries belong to different types of institutional regimes, we expect that findings differ.

Although nation-specific trends are observed, average retirement ages have increased in all three countries between the 1990s and the 2000s. While this may reflect the economic boom in the mid-2000s, the occurrence of major policy reforms in all three counties suggests that these trends may equally be due to a shift from early exit policies in the 1990s to an active ageing paradigm in the 2000s. Yet, despite this policy re-orientation, we find considerable crossnational differences concerning the average retirement age. Although Germany abandoned most state-financed early retirement pathways, retirement transitions on average occur at an earlier age than in England and Japan. Furthermore, we find cross-national differences regarding the nature and quality of this transition. In Germany, at the time of the data collection, firms still used early retirement schemes, resulting in a considerable share of involuntary exits due to a lack of alternative employment options. In England, the share of involuntary exits is only modestly lower: a considerable proportion retire involuntarily due to redundancies and illhealth. In Japan, the incidence of involuntary retirement is the lowest, especially when controlling for health, reflecting the institutional context which prescribes that Japanese employers provide employment up until pension age.

Furthermore, we find intra-national differences, suggesting that individuals from different socio-economic groups have different degrees of choice over retirement. For those with low education levels, we find that Germans have long been in an advantageous position as they could still use financially-attractive early retirement options. In contrast, lowly-educated Japanese and English workers are disadvantaged, as they have to continue working for financial reasons, but often experience ill-health. Furthermore, Japanese low-qualified workers have a lower chance of being redeployed/rehired after age 60, while English low-qualified workers face a higher risk of being made redundant compared to their higher-qualified peers. Consequently, in England and Japan, lower-educated individuals tend to retire involuntarily. Thus, social welfare in terms of state pension provision has an impact on the degree of choice over retirement, especially for those on low income.

We find little difference in the degree of choice experienced among English men and women. Contrary to this, German men exit the labour market more often involuntarily than women. Similarly, Japanese data indicates that retirement is not a likely transition experienced by women, who, instead, consider the transition as an increasing focus on homemaking. Concerning firm size, our results suggest that individuals in small organisations have more 
choice than workers in medium-sized and large organisations. They are more likely to work longer but tend to exit involuntarily because of ill-health. In comparison, workers in larger firms retire earlier than workers in smaller firms, but can count on formalised early retirement schemes in Germany, and have higher chances of being redeployed/rehired in Japan. Finally, trends over time suggest an improvement with regard to choice as the incidence of voluntary retirement increased in England and Germany. Yet in Japan, where actual retirement ages were high already in the 1990s, the shift to longer employment apparently comes at the cost of higher ill-health-related involuntary retirement. This suggests that there may be limits to the extension of working lives.

This study has limitations, such as the data, as discussed above. Also, by using self-reported complete work cessation as the work-retirement transition timing, we cannot account for the increasing heterogeneity and fluidity of this transition. Nevertheless, we show how nationalspecific institutions mediate both retirement transitions and variations in the degree of choice regarding retirement decisions. This allows us to identify specific problem groups under varying institutional conditions. Yet, retirement patterns might still be changing as the current political move towards 'late retirement' continues, even if employers and some governments are reverting back to early retirement during periods of recession. Nevertheless, previouslysheltered groups may be exposed to higher risks. As argued, in Germany, lower-qualified workers, who were able to retire early under financially-favourable conditions in the 1990s, will be decreasingly able to do so under the 'active ageing' paradigm. Furthermore, it remains to be seen under which conditions younger cohorts of women, often with an increasing labour force attachment, will retire in Germany and Japan. There thus remains a need for further research. 


\section{REFERENCES}

Abe, Y. (2011), "The Equal Employment Opportunity Law and labor force behavior of women in Japan", Journal of the Japanese and International Economies, 25:1, 39-55.

Banks, J., Blundell, R., Bozio, A., and Emmerson, C. (2008), Releasing jobs for the young? Early retirement and youth unemployment in the United Kingdom, IFS Working Paper 10/02. London: IFS.

Bennett, J. and Möhring, K. (2015), "Cumulative (Dis)advantage? The Impact of Labour Market Policies on Late Career Employment from a Life Course Perspective", Journal of Social Policy, 44:2,213-233.

Blöndal, S. and Scarpetta, S. (1999), "The retirement decision in OECD countries", OECD Economics Department Working Paper. Paris: OECD.

Blossfeld, H.-P., Buchholz, S. and Hofäcker, D. (Eds) (2006), Globalization, Uncertainty and Late Careers in Society. London: Routledge.

Blossfeld, H.-P., Buchholz, S. and Kurz, K. (Eds) (2011), Ageing Populations, Globalization and the Labor Market: Comparing Late Working Life and Retirement in Modern Societies. Cheltenham: Edward Elgar.

Casey, B. (2005), "The employment of older people: Can we learn from Japan?", Geneva Papers on Risk: Issues and Practice, 30,620-637.

Christensen, K., Doblhammer, G., Rau, R. and Vaupel, J. (2009), "Ageing populations: The challenges ahead". The Lancet, 374,1196-1208.

DePreter, H., Van Looy, D., \& Mortelmans, D. (2013), “Individual and institutional push and pull factors as predictors of retirement timing in Europe: A multilevel analysis”, Journal of Aging Studies, 27(4): 299-307.

Dorn, D. and Sousa-Poza, A. (2010), "'Voluntary' and 'involuntary' early retirement: An international analysis", Applied Economics, 42:4,427-438.

Ebbinghaus, B. (2006), Reforming Early Retirement in Europe, Japan and the USA. Oxford: Oxford University Press.

Ebbinghaus, B. and Hofaecker, D. (2013), Reversing early retirement in advanced welfare economies: A paradigm shift to overcome push and pull factors. Comparative Population Studies, 38(4): 807-840.

EUROFOUND (2012), Impact of the Recession on Age Management Policies. Dublin: Eurofound.

Fasang, A. (2010), Retirement: Institutional pathways and individual trajectories in Britain and Germany. Sociological Research Online, 15(2): 1. 
Flynn, M. (2010), The United Kingdom government's “business case” approach to the regulation of retirement. Ageing \& Society, 30(03): 421-443.

Flynn, M., Schroder, H., Higo, M. and Yamada, A. (2014), Government as institutional entrepreneur: Extending working life in the UK and Japan. Journal of Social Policy, 43(3): 535-553.

Flynn, M., Upchurch, M., Muller-Camen, M. and Schroder, H. (2013), Trade union responses to ageing workforces in the UK and Germany. Human Relations, 66(1): 45-64.

Hall, P.A. and Soskice, D. (2001), Varieties of Capitalism: The Foundation of Comparative Advantage. Oxford: Oxford University Press.

Hirsch, D. 2003. Crossroads after 50: Improving choices in work and retirement. Bristol: Policy Press.

Hofaecker, D. (2010), Older workers under Globalization: An international comparison of retirement and late-career patterns among older workers in Western industrialized countries, Cheltenham/Northampton, MA: Edward Elgar.

Hofaecker, D. and Naumann, E. (2015), The emerging trend of work beyond retirement age in Germany; Zeitschrift fuer Gerontologie und Geriatrie, 48(5): 473-479.

Ichimura, H. and Shimizutani, S. (2012), "Retirement Process in Japan: New Evidence from Japanese Study on Aging and Retirement (JSTAR)". In J.P. Smith and M. Majmundar (Eds.), Aging in Asia: Findings from New and Emerging Data Initiatives (pp.173-206). Washington: National Academy Press.

Koenen, F., Reichert, T. and Zapf, I. (2009), "Freiwillige und unfreiwillige Frühverrentung in Deutschland". In H. Engelhardt (Ed.), Altern in Europa (pp.57-91). Bamberg: University of Bamberg Press.

Kohli, M. and Rein, M. (1991), The changing balance of work and retirement. In: M. Kohli, M. Rein, A.-M. Guillemard and H. van Gusteren (Eds.) Time for retirement: Comparative studies of early exit from the labor force. Cambridge: Cambridge University Press.

Lain, D. (2012), "Working past 65 in the UK and the USA: segregation into Lopaq occupations?". Work, Employment \& Society, 26,78-94.

Leisering, L. (2003), "Government and the Life Course". In J.T. Mortimer and M.J. Shanahan (Eds.), Handbook of the Life Course (pp.205-225). New York: Kluwer.

Maitland, A. (2010), Working Better: The over 50s, the new work generation. Manchester: Equality and Human Rights Commission.

McNair, S. (2010), Learning and Work in Later Life. London: Nuffield Foundation. 
McNair, S., Flynn, M., Owen, L., Humphreys, C. and Woodfield, S. (2004), Changing Work in Later Life: A Study of Job Transitions. Guildford: University of Surrey.

Mood, C. (2010), "Logistic regression: Why we cannot do what we think we can do, and what we can do about it", European Sociological Review, 26, 67-82.

Muller-Camen, M., Croucher, R., Flynn, M. and Schroder, H. (2011), National institutions and employers' age management practices in Britain and Germany: 'Path dependence' and option exploration. Human Relations, 64(4): 507-530.

OECD (1999), Training of adult workers in OECD countries. OECD Employment Outlook, Paris: OECD.

OECD (2005), Ageing and Employment Policies, Paris: OECD.

OECD (2011), Pensions at a Glance 2011, Paris: OECD.

OECD (2013), Scoreboard on Older Workers, Paris: OECD.

OECD (2014), OECD Stat Extracts, Retrieved on 20 May 2014 from http://stats.oecd.org/.

Oka, M. (2013), "Older workers in Japan: the present situation and the future challenges". In P.

Taylor (Ed.), Older Workers in an Ageing Society: (pp.62-68). Cheltenham: Edward Elgar.

Phillipson, C. (2013), "Reconstructing Work and Retirement: Labour Market Trends and Policy Issues". In: J. Field, R. Burke and C. Cooper (Eds.) The SAGE Handbook of Aging, Work and Society. London: Sage.

Quine, S., Wells, Y., De Vaus, D., and Kendig, H. (2007), "When choice in retirement decisions is missing: Qualitative and quantitative findings of impact on well-being”, Australasian Journal on Ageing, 26,4:173-179.

Reeuwijk, K., de Wind, A., Westerman, M., Ybema, J. F., van der Beek, A., and Geuskens, G. (2013), "All those things together made me retire': qualitative study on early retirement among Dutch employees". BMC Public Health, 13,1: 516-527.

Schroder, H., Hofaecker, D. and Muller-Camen, M. (2009), HRM and the employment of older workers: Germany and Britain compared. International Journal of Human Resources Development and Management, 9(2-3): 162-179.

Schroder, H., Muller-Camen, M. and Flynn, M. (2014), The management of an ageing workforce: organisational policies in Germany and Britain. Human Resource Management Journal, 24(4): 394-409.

Seike A. and Yamada A. (2004), Kōreisha shūrou no Keizaigaku, Tokyo: Nihon Keizai Shinbunsha. 
Shimizutani, H. (2011), "A new anatomy of the retirement process in Japan", Japan and the World Economy, 23,3: 141-152.

Trampusch, C. (2003), "Institutional resettlement: The case of early retirement in Germany". In W. Streeck, and K. Thelen (Eds.), Beyond Continuity: Institutional Change in Advanced Political Economies (pp.203-227). Oxford: Oxford University Press.

van Berkel, R., Borghi, V., Carmel, E., Hamblin, K. and Papadopoulos, T. (2007), "Governing the activation of older workers in the European Union". International Journal of Sociology and Social Policy, 27,387-400.

Walker, A. (1980), "The social creation of poverty and dependency in old age". Journal of Social Policy, 9,01: 49-75.

Walker, A. (1985), "Early retirement: Release or refuge from the labour market". The Quarterly Journal of Social Affairs, 1,3: 211-229.

Walker, A. (1998), "Age and employment". Australasian Journal on Ageing, 17: 99-103.

Walker, A. (2002), "A strategy for active ageing", International Social Security Review, 55:121-139.

Walker, A. (2005), "The emergence of age management in Europe". International Journal of Organisational Behaviour, 10,1: 685-697.

Walker, A., and DLitt (2000), Public policy and the construction of old age in Europe. The Gerontologist, 40,3: 304-308.

Weyman, A. and Buckingham, A. (2013), Extending Working Life: Audit of Research Relating to the Impact on NHS Employees. Leeds: NHS.

Wood, G., Wilkinson, G. and Harcourt, M. (2008), "Age discrimination and working life: Perspectives and contestations". International Journal of Management Reviews, 10, 425-442.

Yamada, A. and Higo, M. (2011), Institutional barriers to work beyond retirement in an aging Japan: Evidence from a recent employee survey". Contemporary Japan, 23,157-186. 
Table 1: Institutional characteristics, Japan, Germany, UK

\begin{tabular}{|l|l|l|l|l|l|}
\hline & Pull & Push & Stay & Recent trend & Social inequality \\
\hline Japan & Low & Low & High & $\begin{array}{l}\text { Further increase in } \\
\text { retirement ages, Re- } \\
\text { deployment after } \\
\text { retirement }\end{array}$ & $\begin{array}{l}\text { Modest inter- } \\
\text { educational cleavages } \\
\text { until retirement, high- } \\
\text { skilled workers most } \\
\text { likely to become } \\
\text { redeployed }\end{array}$ \\
\hline Germany & High & High & Low & $\begin{array}{l}\text { Shift from early exit to } \\
\text { active ageing, reduction of } \\
\text { pull incentives but only } \\
\text { modest and unbalanced } \\
\text { increase in stay policies }\end{array}$ & $\begin{array}{l}\text { Lower-skilled workers } \\
\text { traditionally inclined } \\
\text { to early exit, yet } \\
\text { currently under- } \\
\text { represented in active } \\
\text { ageing measures }\end{array}$ \\
\hline UK & Low & Low & Low & $\begin{array}{l}\text { Abolition of default } \\
\text { retirement, Measures } \\
\text { lowering age } \\
\text { discrimination, } \\
\text { privatisation of pension } \\
\text { risks }\end{array}$ & $\begin{array}{l}\text { Higher-skilled workers } \\
\text { most able to 'decide' } \\
\text { on early exit, lower- } \\
\text { skilled workers work } \\
\text { longer for financial } \\
\text { reasons }\end{array}$ \\
\hline
\end{tabular}

Source: Own illustration 
Table 2: Reasons for Retirement and classification into voluntary/involuntary retirement

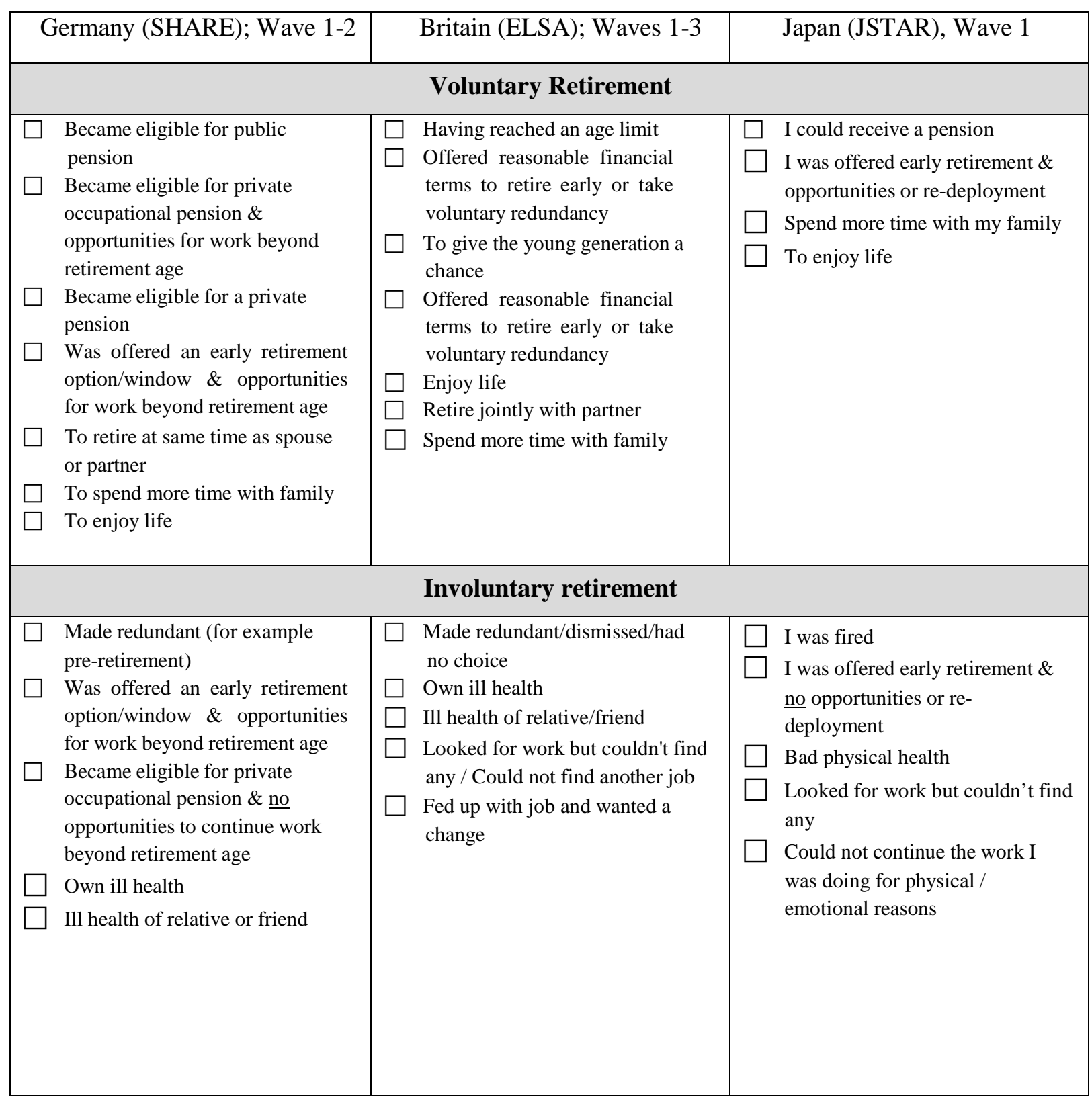

Source: Own illustration 
Table 3: Average Exit Age and Incidence of Involuntary Retirement in Germany, England and Japan

\begin{tabular}{|c|c|c|c|c|c|c|c|c|c|}
\hline & \multicolumn{3}{|c|}{ Average exit age } & \multicolumn{3}{|c|}{$\begin{array}{l}\text { Involuntary retirement, } \\
\text { (incl. health) as } \\
\text { percentage of all } \\
\text { retirement transitions }\end{array}$} & \multicolumn{3}{|c|}{$\begin{array}{c}\text { Involuntary retirement } \\
\text { (excl. health) as } \\
\text { percentage of all } \\
\text { retirement transitions }\end{array}$} \\
\hline & $\begin{array}{l}\text { German } \\
y\end{array}$ & $\begin{array}{l}\text { Englan } \\
d\end{array}$ & $\begin{array}{c}\text { Japa } \\
n\end{array}$ & $\begin{array}{c}\text { German } \\
y\end{array}$ & $\begin{array}{c}\text { Englan } \\
d\end{array}$ & $\begin{array}{c}\text { Japa } \\
n\end{array}$ & $\begin{array}{c}\text { German } \\
y\end{array}$ & $\begin{array}{c}\text { Englan } \\
d\end{array}$ & $\begin{array}{c}\text { Japa } \\
n\end{array}$ \\
\hline & & & & 47.2 & 43.8 & & 37.1 & 29.5 & \\
\hline Men & 60.03 & 61.60 & 62.79 & 52.4 & 44.0 & 42.5 & 42.2 & 30.1 & 22.0 \\
\hline Women & 58.98 & 60.10 & 61.48 & 40.2 & 43.6 & & 30.5 & 28.8 & $\mathrm{xxx}$ \\
\hline $50-54$ & - & - & - & 73.0 & 49.3 & $\mathrm{xxx}$ & 55.5 & 36.8 & $\mathrm{xxx}$ \\
\hline 55-59 & - & - & - & 78.0 & 55.3 & $\mathrm{xxx}$ & 72.8 & 37.7 & $\mathrm{xxx}$ \\
\hline $60-64$ & - & - & - & 39.7 & 54.0 & 40.2 & 30.0 & 38.7 & 27.3 \\
\hline $65-69$ & - & - & - & 11.7 & 44.6 & 36.8 & 2.8 & 29.8 & 10.2 \\
\hline $1990-1999$ & 59.22 & 60.54 & 60.58 & 48.1 & 44.6 & 37.6 & 41.5 & 30.0 & 26.9 \\
\hline $2000-2008$ & 60.05 & 61.30 & 63.58 & 45.7 & 41.8 & 44.6 & 37.7 & 28.2 & 19.3 \\
\hline $\begin{array}{l}\text { Primary/Non } \\
\text { e }\end{array}$ & $\mathrm{xxx}$ & 61.58 & $\mathrm{XXX}$ & $\mathrm{xxx}$ & 47.9 & $\mathrm{xxx}$ & $\mathrm{xxx}$ & 31.2 & $\mathrm{XxX}$ \\
\hline $\begin{array}{l}\text { Lower } \\
\text { secondary }\end{array}$ & 60.00 & 60.69 & 63.6 & 42.2 & 42.0 & 50.8 & 28.7 & 28.9 & 27 \\
\hline $\begin{array}{l}\text { Upper } \\
\text { secondary }\end{array}$ & 59.37 & 60.62 & 62.49 & 49.9 & 39.3 & 39.4 & 40.6 & 28.1 & 19.5 \\
\hline Tertiary & 59.87 & 59.58 & 61.97 & 42.7 & 38.0 & 32.7 & 32.8 & 26.5 & 19.6 \\
\hline $\begin{array}{l}\text { Firm size: } \\
\text { small }\end{array}$ & 59.46 & $N A$ & 64.1 & 43.9 & $N A$ & 42.2 & 31.6 & $N A$ & 133 \\
\hline $\begin{array}{l}\text { Firm size: } \\
\text { medium }\end{array}$ & 59.36 & & 62.4 & 55.6 & & 45.2 & 47.4 & & 30.1 \\
\hline $\begin{array}{l}\text { Firm size: } \\
\text { large }\end{array}$ & 58.61 & & 61.9 & 60.0 & & 35.4 & 54.2 & & 25.5 \\
\hline $\begin{array}{l}\text { Sector: } \\
\text { Public }\end{array}$ & 59.46 & & & 48.7 & & & 39.5 & & \\
\hline $\begin{array}{l}\text { Sector: } \\
\text { Primary }\end{array}$ & 59.19 & & $N A$ & 48.2 & & $N A$ & 44.9 & & $N A$ \\
\hline $\begin{array}{l}\text { Sector: } \\
\text { Secondary }\end{array}$ & 59.27 & & & 52.4 & & & 42.7 & & \\
\hline $\begin{array}{l}\text { Sector: } \\
\text { Tertiary }\end{array}$ & 59.48 & & & 47.1 & & & 35.9 & & \\
\hline
\end{tabular}

Source: ELSA waves 1-3, SHARE wave 1-2, JSTAR wave 1 (own calculations) $\mathrm{xxx}=$ not calculated due to small sample size; NA=Not Available 
Table 4: Likelihood of voluntary exit in Germany 1990-2006, logistic regression

\begin{tabular}{|c|c|c|c|c|c|c|c|c|}
\hline & \multicolumn{4}{|c|}{$\begin{array}{l}\text { voluntary retirement } \\
\text { (with health reasons) }\end{array}$} & \multicolumn{4}{|c|}{$\begin{array}{c}\text { Voluntary retirement } \\
\text { (without health reasons) }\end{array}$} \\
\hline $\mathrm{C}_{2}$ & $\begin{array}{r}\text { Margi } \\
\text { effec }\end{array}$ & & $\begin{array}{l}\text { Odd } \\
\text { ratio }\end{array}$ & & $\begin{array}{r}\text { Margina } \\
\text { effects }\end{array}$ & & $\begin{array}{c}\text { Odds } \\
\text { ratios }\end{array}$ & \\
\hline Age 55-59 & 0.036 & & 1.22 & & -0.026 & & 0.84 & \\
\hline Age 60-64 & 0.388 & $* * *$ & 9.13 & $* * *$ & 0.330 & $* * *$ & 8.36 & $* * *$ \\
\hline Age 65-69 & 0.684 & $* * *$ & 48.56 & $* * *$ & 0.832 & $* * *$ & 205.74 & $* * *$ \\
\hline Age70 plus & 0.073 & $* * *$ & 1.53 & $* * *$ & 0.091 & $* * *$ & 1.82 & $* * *$ \\
\hline Male (ref female) & -0.163 & $* * *$ & 0.40 & $* * *$ & -0.156 & $* * *$ & 0.37 & $* * *$ \\
\hline \multicolumn{9}{|l|}{$\begin{array}{l}\text { Education: } \\
\text { Lower secondary and less (ref.) }\end{array}$} \\
\hline Upper secondary & 0.085 & $* * *$ & 1.78 & $* * *$ & -0.010 & & 0.64 & $*$ \\
\hline Tertiary & 0.116 & $* * *$ & 1.30 & & 0.048 & $*$ & 0.62 & $*$ \\
\hline Exit cohort: 1990s (ref. 2000s) & 0.098 & $* * *$ & 1.76 & $* *$ & 0.083 & $* * *$ & 1.01 & $* * *$ \\
\hline Firm size: small (ref.: medium) & 0.055 & $* * *$ & 1.35 & $* * *$ & 0.112 & $* * *$ & 2.04 & $* * *$ \\
\hline Firm size: large (ref.: medium) & 0.055 & $* *$ & 1.36 & $* *$ & 0.060 & $* * *$ & 1.42 & ** \\
\hline Industry: secondary (ref.: all other) & -0.017 & & 0.91 & & -0.015 & & 0.90 & \\
\hline Industry: Public (ref. Private) & 0.021 & & 1.13 & & 0.054 & & 1.41 & $* * *$ \\
\hline Upper secondary*1990s & & & 0.87 & & & & 1.61 & $*$ \\
\hline Tertiary * 1990s & & & 1.72 & $*$ & & & 2.70 & $* * *$ \\
\hline Constant & & & 0.08 & $* * *$ & & & 0.29 & $* * *$ \\
\hline
\end{tabular}

Source: SHARE Waves 1 and 2 (own calculations)

note: SHARE also provides information on type of industry (e.g. public and private). A regression including type of industry shows insignificant effect of it on likelihood of voluntary exit.

*** $\mathrm{p}<0.01,{ }^{* *} \mathrm{p}<0.05, * \mathrm{p}<0.1$ 
Table 5: Likelihood of voluntary exit in England 1990-2006. logistic regression

\begin{tabular}{|c|c|c|c|c|c|c|c|c|}
\hline & \multicolumn{4}{|c|}{$\begin{array}{l}\text { voluntary retirement } \\
\text { (with health reasons) }\end{array}$} & \multicolumn{4}{|c|}{$\begin{array}{c}\text { Voluntary retirement } \\
\text { (without health reasons) }\end{array}$} \\
\hline & \multicolumn{2}{|c|}{$\begin{array}{c}\text { Marginal } \\
\text { effects }\end{array}$} & \multicolumn{2}{|c|}{$\begin{array}{l}\text { Odds } \\
\text { ratios }\end{array}$} & \multicolumn{2}{|c|}{$\begin{array}{c}\text { Marginal } \\
\text { effects }\end{array}$} & \multicolumn{2}{|l|}{$\begin{array}{l}\text { Odds } \\
\text { ratios }\end{array}$} \\
\hline Age 55-59 & -0.022 & & 0.906 & & -0.002 & & 0.992 & \\
\hline Age 60-64 & 0.034 & & 1.161 & & 0.014 & & 1.062 & \\
\hline Age 65-69 & 0.175 & $* * *$ & 2.097 & $* * *$ & 0.150 & $*$ & 1.944 & * \\
\hline Age70 plus & 0.309 & $* * *$ & 3.804 & $* * *$ & 0.245 & $* * *$ & 3.270 & $* * *$ \\
\hline Male (ref female) & -0.049 & $* * *$ & 0.810 & $* * *$ & -0.044 & $* *$ & 0.804 & $* *$ \\
\hline \multicolumn{9}{|l|}{ Education: } \\
\hline Lower secondary and less (ref.) & & & & & & & & \\
\hline Upper secondary & 0.014 & & 1.065 & & -0.004 & & 0.978 & \\
\hline Tertiary & -0.040 & & 0.839 & & -0.048 & & 0.772 & \\
\hline Primary/none & -0.132 & $* * *$ & 0.567 & $* * *$ & -0.112 & $* * *$ & 0.568 & $* * *$ \\
\hline Exit cohort: 1990s (ref. 2000s) & -0.210 & $* * *$ & 0.407 & $* * *$ & -0.184 & $* * *$ & 0.398 & $* * *$ \\
\hline Upper secondary*1990s & & & 1.436 & $*$ & & & 1.431 & \\
\hline Tertiary * 1990s & & & 1.705 & & & & 1.632 & \\
\hline primary/none*1990s & & & 1.398 & $*$ & & & & $* *$ \\
\hline Constant & & & 1.461 & & & & 2.752 & $* * *$ \\
\hline
\end{tabular}

Source: ELSA Waves 1-3 (own calculations)

note: ELSA does not provide information on firm size and sector.

*** $\mathrm{p}<0.01,{ }^{* *} \mathrm{p}<0.05,{ }^{*} \mathrm{p}<0.1$ 
Table 6: Likelihood of voluntary exit in Japan 1990-2007 (men only), logistic regression

\begin{tabular}{|c|c|c|c|c|}
\hline & \multicolumn{2}{|c|}{$\begin{array}{l}\text { voluntary retirement } \\
\text { (with health reasons) }\end{array}$} & \multicolumn{2}{|c|}{$\begin{array}{c}\text { Voluntary retirement } \\
\text { (without health reasons) }\end{array}$} \\
\hline 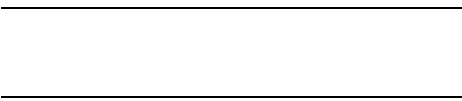 & $\begin{array}{c}\text { Marginal } \\
\text { effects }\end{array}$ & $\begin{array}{c}\text { Odds } \\
\text { ratios }\end{array}$ & $\begin{array}{c}\text { Marginal } \\
\text { effects }\end{array}$ & $\begin{array}{l}\text { Odds } \\
\text { ratios }\end{array}$ \\
\hline \multicolumn{5}{|l|}{ Age 50-59 (ref.) } \\
\hline Age 60-64 & $0.371 * *$ & $5.73 * *$ & $0.249 * *$ & $5.24 * *$ \\
\hline Age 65-69 & $0.477 * * *$ & $9.34 * * *$ & $0.419 * * *$ & $16.32 * * *$ \\
\hline Age 70 plus & $0.378 * *$ & $5.91 * *$ & $0.417 * *$ & $16.10 * *$ \\
\hline \multicolumn{5}{|l|}{$\begin{array}{l}\text { Education: } \\
\text { Lower secondary and lower (ref.) }\end{array}$} \\
\hline Upper secondary & $0.124 *$ & 1.35 & $0.097 *$ & 1.54 \\
\hline Tertiary & 0.199 & 2.54 & 0.100 & 1.85 \\
\hline Exit cohort: 1990s (ref. 2000s) & $0.119 *$ & $2.89 * *$ & 0.019 & 1.47 \\
\hline Firm size: small (ref.: medium) & 0.046 & 1.22 & 0.134 & 2.42 \\
\hline Firm size: large (ref.: medium) & $0.111 *$ & 1.61 & 0.058 & 1.47 \\
\hline Upper secondary*1990s & & 2.44 & & 1.61 \\
\hline Tertiary*1990s & & 0.73 & & 1.05 \\
\hline Constant & & $0.165 * *$ & & 0.366 \\
\hline
\end{tabular}

Source: JSTAR Wave 1 (own calculations)

note: only males are included for the analysis of Japan because the number of Japanese women aged 50 and over in the labour market is too small to give feasible results; controlled for missing values; JSTAR does not provide information on sector

$* * * \mathrm{p}<0.01, * * \mathrm{p}<0.05,{ }^{*} \mathrm{p}<0.1$ 
Table A1: Detailed Reasons for Retirement (Germany)

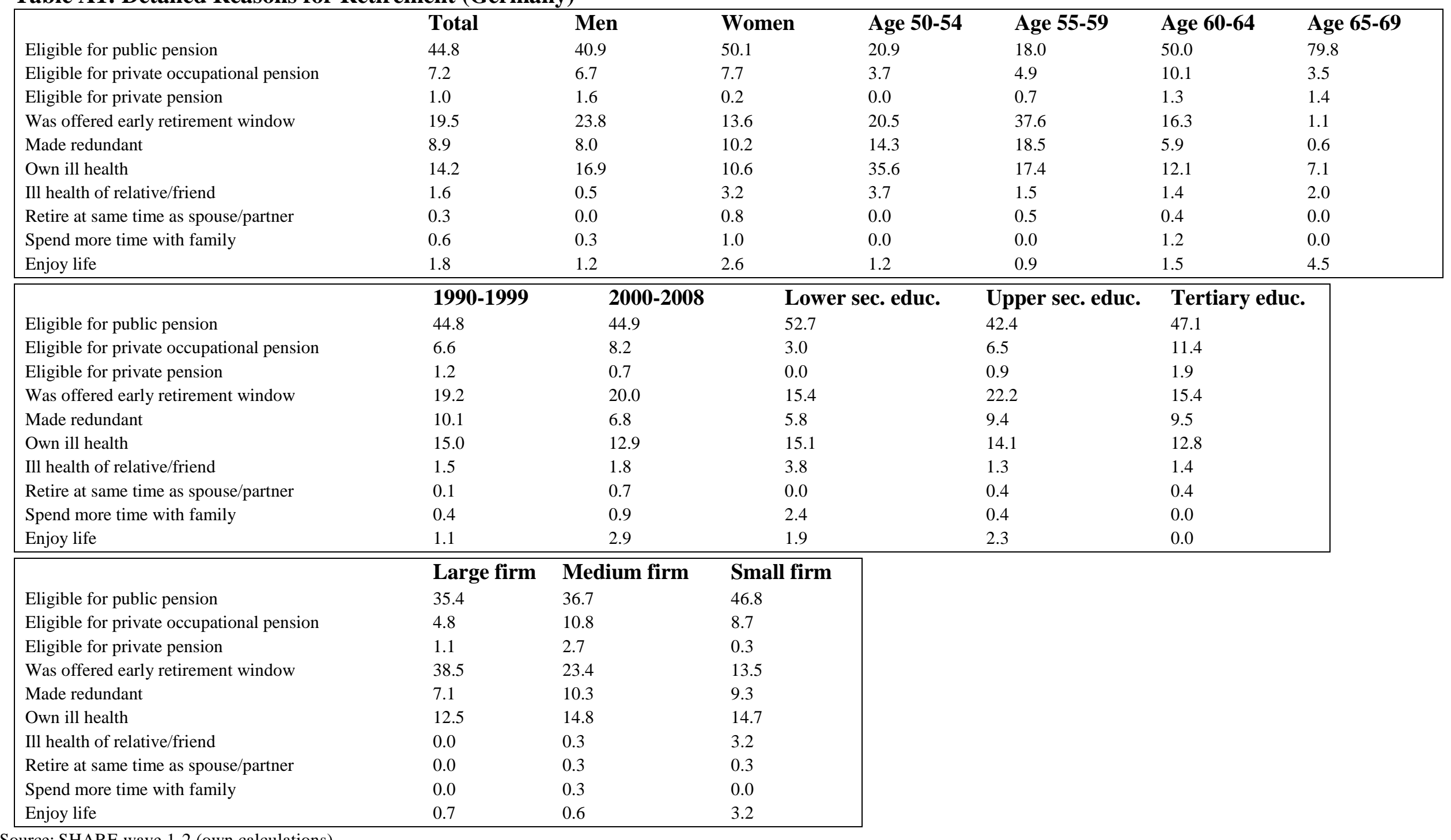

Source: SHARE wave 1-2 (own calculations) 
Table A2: Detailed Reasons for Retirement (England)

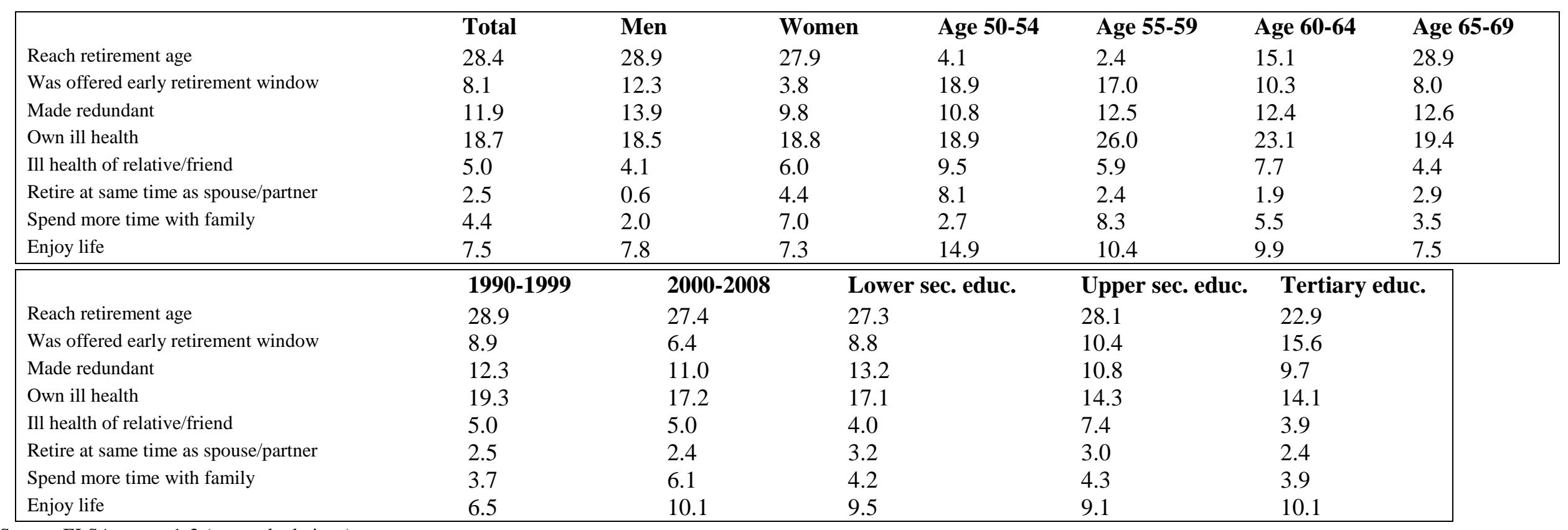

Source: ELSA waves 1-3 (own calculations) 
Table A3: Detailed Reasons for Retirement (Japan, men only)

\begin{tabular}{|c|c|c|c|c|c|c|}
\hline & Total & Age 60-64 & Age 65-69 & Age 70+ & 1990-1999 & $2000-2008$ \\
\hline Reaching Retirement age/retiring beyond 65 & 36.6 & 36.7 & 40.8 & 36.6 & 38.5 & 35.7 \\
\hline Offered early exit & 3.6 & 3.0 & .8 & & 3.7 & 3.6 \\
\hline Bad physical health & 3.4 & .6 & 6.4 & 2.4 & .9 & 4.4 \\
\hline Spend more time with family & 2.2 & 1.8 & 2.4 & & 3.7 & 1.6 \\
\hline Enjoy life & 6.4 & 7.7 & 6.4 & 4.9 & 7.3 & 6.0 \\
\hline Looked for work but could not find any & 4.2 & 3.0 & 6.4 & 4.9 & 4.6 & 4.0 \\
\hline Physical or emotional reasons & 22.9 & 17.2 & 23.2 & 43.9 & 13.8 & 26.9 \\
\hline Retired, but offered rehiring alternative & 12.3 & 13.6 & 13.6 & 7.3 & 12.8 & 12.0 \\
\hline Retired early and not offered rehiring alternative & 8.4 & 16.6 & & & 14.7 & 5.6 \\
\hline
\end{tabular}

\begin{tabular}{|c|c|c|c|c|c|c|}
\hline Reaching Retirement age/retiring bevond 65 & $\begin{array}{l}\text { Lower sec. educ. } \\
37.9\end{array}$ & $\begin{array}{l}\text { Upper sec. educ. } \\
35.9\end{array}$ & $\begin{array}{l}\text { Tertiary educ. } \\
36.4\end{array}$ & $\begin{array}{l}\text { Small firm } \\
46.7\end{array}$ & $\begin{array}{l}\text { Medium firm } \\
29.0\end{array}$ & $\begin{array}{l}\text { Large firm } \\
35.4\end{array}$ \\
\hline Offered early exit & 3.8 & 4.1 & 1.8 & 4.4 & 2.2 & 5.3 \\
\hline Bad physical health & 3.8 & 2.9 & 3.6 & 2.2 & 1.1 & 3.5 \\
\hline Spend more time with family & .8 & 3.5 & 1.8 & & 1.1 & 3.5 \\
\hline Enjoy life & 2.3 & 10.0 & 5.5 & 4.4 & 8.6 & 7.1 \\
\hline Looked for work but could not find any & 4.5 & 4.1 & 3.6 & & 6.5 & 5.3 \\
\hline Physical or emotional reasons & 28.8 & 21.8 & 12.7 & 31.1 & 20.4 & 9.7 \\
\hline Retired, but offered rehiring alternative & 8.3 & 11.2 & 23.6 & 6.7 & 16.1 & 18.6 \\
\hline Retired early and not offered rehiring alternative & 9.8 & 6.5 & 10.9 & 4.4 & 15.1 & 11.5 \\
\hline
\end{tabular}

Source: JSTAR wave 1 (own calculations)

${ }^{i}$ Unlike variables such as job status and income, qualifications were measured in a harmonized fashion within all three surveys and could be reconstructed.

ii This paper uses data from SHARE release 2.5.0, as of May 24th 2011. The SHARE data collection has been primarily funded by the European Commission through the 5th framework programme (project QLK6-CT2001-00360 in the thematic programme Quality of Life), through the 6th framework programme (projects SHARE-I3, RII-CT- 2006-062193, COMPARE, CIT5-CT-2005-028857, and SHARELIFE, CIT4-CT-2006- 
028812) and through the 7th framework programme (SHARE-PREP, 211909 and SHARE-LEAP, 227822). Additional funding from the U.S. National Institute on Aging (U01 AG09740-13S2, P01 AG005842, P01 AG08291, P30 AG12815, Y1-AG-4553-01 and OGHA 04-064, IAG BSR06-11, R21 AG025169) as well as from various national sources is gratefully acknowledged (see www.share- project.org for a full list of funding institutions).

iii The English Longitudinal Study of Ageing was developed by a team of researchers based at University College London, the Institute for Fiscal Studies and NatCen Social Research. The funding is provided by the

National Institute on Aging (grant RO1AG017644) and a consortium of UK government departments coordinated by the Office for National Statistics. The data are lodged with the UK Data Archive.

iv The Japanese Study of Aging and Retirement (JSTAR) was conducted by the Research Institute of Economy, Trade and Industry (RIETI) and Hitotsubashi University. 